\title{
COMPARATIVE ANALYSIS OF FACEBOOK AND COMMUNICATION ACTIVITIES OF THE MOUNTAIN HOTELS IN STARA PLANINA, KOPAONIK AND ZLATIBOR
}

\section{Radmila Živković , Angelina Njeguš, Marija Zlatanović, Jelena Gajić, Ivana Brdar}

Singidunum University, Faculty of Tourism and Hospitality Management 32 Danijelova Street, Belgrade, Serbia

\begin{abstract}
:
Communication strategies with the consumers of tourism products and services have significantly transformed in recent years with the advent of social media and online information. According to numerous authors, social media represent a hybrid form of traditional integrated marketing communications with the increased effect of WOM (word of mouth) communication, which enables the exchange of information between users/consumers. The transparency of social media provides the hoteliers with necessary feedback and opens up new communication channels. Modern consumers possess greater knowledge and higher expectations than before. The purpose of the research conducted on a sample of mountain hotels in Serbia using web metrics was to determine guest perception and satisfaction with the hotels at the most popular Serbian mountain destinations. The results show that social networks can be used successfully by service providers to improve the understanding of guests' needs, as well as to enhance business performance and revenue. By maintaining long-term relationships with guests, hoteliers can build stronger and more enduring connections that will result in new purchases and more efficient WOM (word of mouth).
\end{abstract}

\author{
Key words: \\ marketing communications, \\ mountain hotels, \\ social media, \\ consumers.
}

\section{INTRODUCTION}

In the past, marketing theory was focused more on "how to sell", whereas today more emphasis is placed on consumers, pushing boundaries from thinking in terms of financial transactions to developing relationships. Therefore, the basic goal of marketing activities of a company doing business in the area of tourism, aside from developing products and services, innovating processes, internal and external communication, analysis of competition, etc., is to satisfy the needs and wishes of consumers/tourists in a way that secures the increase in sales of a tourist product and making long-term profit.
The key strategy that tourist companies employ to learn about consumers-tourists is establishing the facts (gathering and analysing data) about their past and present purchases and the level of their satisfaction with the choice and quality of tourist products. Research and analysis of the obtained data present information and give directions for adjusting offers, assessment of the possibility for increasing tourist traffic, designing successful communication with certain emitting markets, evaluation of the importance of some elements of the tourist product of a destination etc.

From the point of view of tourist demand, there came to a change in the structure of tourists' wishes 
and expectations, which came out of the frame of the industrial tourist model and shaped the tourism in accordance with a new lifestyle and new values. Greater expectations of tourists have been incited by media and telecommunication, higher degree of education and previous experience and knowledge. The same factors influence faster transfer of information. The Internet facilitates comparison of destinations and hotels, and thus saves time and enables direct booking. Understanding the consumers and the decisionmaking process to purchase or use tourism products is the foundation of marketing strategy (Cohena et al., 2014; Živković, 2013; Fratu, 2011).

The aim of this paper is to point to the merit and importance of online communication in tourism and hotel management in order to develop more efficient marketing communication strategies and actions. The purpose of this research was to establish the perception and attitudes of guests in the sample mountain hotels in Serbia by means of web metrics.

\section{MODERN COMMUNICATON IN TOURISM AND HOTEL MANAGEMENT}

Modern tourists are well informed due to information technologies, and therefore can easily compare several similar offers. The traditional approach used to be mostly one-directional, comprising active company and passive consumer (Minazzi, 2015). Marketing 2.0, which is the result of the development of Web 2.0 generation, is actually the consumer-oriented marketing (Kotler et al., 2010). Upon encountering this newer generation of Web, the so-called semantic web, marketing turns to personalisation and consumer engagement and becomes increasingly intelligent. As a result, it evolves into the intelligent web marketing or Marketing 3.0. The comparison of marketing generations in relation to web development is presented in Table 1.

Information and communication systems enable collecting and analysing information with the aim of creating new products/services adapted to meet the needs of different users. The advantage of such comparison is that it encourages tourist agencies to make innovations based on their strong points and key competencies, which could be further used to manage new knowledge, information and tourist experiences (Živković et al., 2012). Consumers should always know in advance about the type of tourist experience, since in the first phase of decision-making, they are those who choose destinations which reflect beliefs, feelings and attitudes on the possibilities of satisfying their specific needs as tourists (Pull factors). (Kanagaraj \& Bindu, 2013; Bakić, 2010; Fjelstul, 2013)

Information transfer regarding the offer, via media and other marketing channels, previous experience and attitudes of tourists, combined with motivation and socioeconomic characteristics, shape the tourists' perception/image. With the rapid advancement of technology and increase in the number of innovations, numerous important characteristics of products and services the companies want to use in market games have stayed beyond the consumers' field of perception. It is assumed that, for the good positioning of a product or service in the market, it is necessary to possess better previous knowledge and understanding of the way the consumers are informed about rival brands. Information about the market greatly shapes the behaviour of potential consumers.

\begin{tabular}{|c|c|c|c|}
\hline & $\begin{array}{l}\text { Marketing } 1.0 \\
\text { Product-oriented }\end{array}$ & $\begin{array}{c}\text { Marketing } 2.0 \\
\text { Consumer-oriented }\end{array}$ & $\begin{array}{l}\text { Marketing } 3.0 \\
\text { Value-oriented }\end{array}$ \\
\hline Goal & $\begin{array}{l}\text { To sell the product in } \\
\text { mass market }\end{array}$ & $\begin{array}{l}\text { To satisfy the needs and } \\
\text { retain consumers }\end{array}$ & $\begin{array}{l}\text { To meet the emotional and rational } \\
\text { needs of consumers }\end{array}$ \\
\hline Stimulus & Industrial revolution & $\begin{array}{l}\text { Information } \\
\text { technologies }\end{array}$ & $\begin{array}{l}\text { Development of World Wide Web and } \\
\text { introduction of Web } 3.0 \text { generation }\end{array}$ \\
\hline $\begin{array}{l}\text { Marketers' view of } \\
\text { market }\end{array}$ & Mass market & Smarter consumers & $\begin{array}{l}\text { Consumers with all their spiritual, } \\
\text { emotional and rational values }\end{array}$ \\
\hline Key marketing concept & $\begin{array}{l}\text { Market guided by } \\
\text { product }\end{array}$ & Differentiation & $\begin{array}{l}\text { Product value according to consumer } \\
\text { profile }\end{array}$ \\
\hline Value proposition & Functional & $\begin{array}{l}\text { Functional and } \\
\text { emotional }\end{array}$ & $\begin{array}{l}\text { Functional, emotional, spiritual and } \\
\text { rational }\end{array}$ \\
\hline $\begin{array}{l}\text { Interaction with } \\
\text { consumers }\end{array}$ & $\begin{array}{l}\text { Mass communication } \\
\text { (one vs. many) }\end{array}$ & Relation of one vs. one & $\begin{array}{l}\text { Mutually cooperating consumers (many } \\
\text { vs. many) }\end{array}$ \\
\hline
\end{tabular}

Table 1. Comparison of marketing generations

Source: Kotler et al. (2010) 
The process of collecting information in tourism is rather complex and comprises gathering information from different sources, such as tourist agencies, internet portals, video, itineraries, catalogues and brochures on destinations, tour operators, newsletters, info desks, social networks, transportation agencies, etc. Communication messages, broadcasted via television, internet or other channels, work as a recommendation to tourists, and as such, they and their sociological role cannot be overlooked (Živković, 2013; Jansen \& Schuster, 2011).

The Internet has two important roles in this process: openness and the possibility of network creation. The first one relates to the possibility of an individual to participate by creating, sharing information, while the second one relates to the potential for creating more or less cohesive communities/groups - whether we talk about territorially distant groups or already established "place-based community networks", and this intensifies the potential influence on other people (Servon, 2002). As regards this, it is necessary to stress out the impact of reference groups and thought leaders. Reference groups are used as a starting point for comparison by an individual when forming values, attitudes or behaviours. The concept of a reference group is very wide and what is common to different reference groups is that they are all understood by consumers as points of comparison (reference) for evaluating personal actions, beliefs and attitudes. Aside from the visible influence that reference groups have on consumers' behaviour, there is also the significant impact that a person can have on forming values, attitudes and behaviour of a group to which he/she belongs. There are strict individualists who create and nurture their own habits and lifestyle within the frame of group values (Maričić, 2011; Solomon, 2011).

There are numerous reasons why people want to be present on social networks and share their knowledge and experience with other users. People usually become motivated to share important information online when they expect their experience to help or at least be useful to someone. Social psychology dictates that people are social beings who are pleased with the fact that they receive direct response for their contribution (Živković, 2014).

\section{SOCIAL NETWORKS:}

\section{GOALS AND FUNCTIONAL FRAMEWORK}

Social networks have enabled the two-directional process of communication. Nowadays, the role of responsibility and moral support is not only upon the providers of information, but also upon the users participating in the process of informing and sharing that information with other potential users. By describing their needs related to hotel services, the points of satisfaction and dissatisfaction, users give a notion to service providers about how to improve all the parameters of services. Social networks are used by providers with the aim of improving and understanding the needs of their users, and thus improving their business, increasing revenue, keeping old and attracting new users (Hoffman \& Novak, 2009). By building marketing relations via contemporary media, hoteliers build stronger and more durable connections which result in higher sales, repeated purchases and more efficient oral propaganda (Safko, 2010; Green \& Lomano, 2012).

The development of the new Web 3.0 generation has triggered media to set new trends. Social networks represent one of the most used means of online promotion. Social networks as tools for promotion and marketing enable access to a large number of users, comprehension of their needs, as well as adaptation (customisation) of a product or service, which further leads to creating recognisable brands that the users will repeatedly return to. The basic goals of marketing using social networks are shown in Table 2.

\begin{tabular}{cl}
\hline Goals & \multicolumn{1}{c}{ Description } \\
\hline $\begin{array}{c}\text { Building of } \\
\text { relationships }\end{array}$ & $\begin{array}{l}\text { Inbound-marketing; personalisation; en- } \\
\text { gaged consumer }\end{array}$ \\
\hline $\begin{array}{c}\text { Building of } \\
\text { brands }\end{array}$ & $\begin{array}{l}\text { Increase of recognition and loyalty to brend; } \\
\text { word-of-mouth }\end{array}$ \\
\hline Publicity & $\begin{array}{l}\text { Promotions; sharing information and influ- } \\
\text { encing negative perception }\end{array}$ \\
\hline Market & $\begin{array}{l}\text { Analysing results by using analytical tools } \\
\text { for following social networks; learning from } \\
\text { one's clients; analysing consumer profiles } \\
\text { and behaviour }\end{array}$ \\
\hline
\end{tabular}

Table 2. Goals of marketing use of social networks Source: Gunelius (2011)

There are different levels of use of social networks. Kietzmann et al. (2011) suggested the framework containing seven functional blocks: identity, conversations, sharing, presence, relationships, reputation and groups (Table 3). Every developmental block enables comprehension of users' experiences on social networks and their influence on companies.

- Identity: it comprises personal data that users post on social networks, such as their name and surname, age, gender, occupation, location, as well as false representation. Identity represents the basic core of many social media platforms (e.g. Facebook was built as an iden- 
tity base, i.e. setting up of user profiles). The main issue within this block is the privacy of data. Companies can follow demographic data of their users based on their identities.

- Conversations: they point to the amount to which users communicate with each other on social networks. Many social networks have primarily been developed to facilitate communication between users and groups. However, the enormous number of different communication forms and protocols is being transferred, which the companies desire to track and save in their systems. For example, Twitter was developed around the exchange of short messages which mainly represent statements in real time.

- Sharing: it represents the exchange, distribution and acceptance of content among users. Companies want to identify the common social goals of the users or new services that could be interesting to certain social groups. The most popular platforms for content sharing are Tumblr, YouTube, Pinterest, etc. (Stelzner, 2014; Global Web Index, 2014)

- Presence: it subsumes the availability of users on social networks. It also includes the recognition of the users' location, as well as their availability, either in real or virtual environment. The user movements within and outside the network are being followed.

- Relationships: these show the degree of mutual connection among the users. Connection refers to whether they are friends online or they belong to the same group, whether they share some common interests, etc. Companies want to know how to build or maintain longstanding relationships with users.

- Reputation: reputation on social networks is based on trust, i.e. the degree to which users can identify each other as well as themselves. Companies choose specialised metrics to measure their reputation, for instance, to show the number of views or fans.

- Groups: They take into account the degree to which users can form communities or sub communities (e.g. groups of friends or fans).

\section{WEB ANALYSIS: CONCEPT, FRAMEWORK AND TOOLS}

Web analytics is a tool for collecting, measuring, analysing and reporting about web traffic, in order to understand web users' behaviour, with the aim of delivering personalised content, as well as grading, optimising and improving the website efficiency (Clifton, 2014). Web analytics tools are being largely used today for tracking the conduct of businesses and market researches. For instance, by following analytics, we can obtain answers to the following questions:

- Who are the visitors of websites and do they have similar characteristics?

- From which social networks do visitors mainly come to the website?

- Which campaigns increase the sales?

- Which websites trigger visitors to decide upon purchase?

- Which websites do visitors come from?

\begin{tabular}{|c|c|c|}
\hline Name & Description & Problems and metrics \\
\hline Identity & $\begin{array}{l}\text { Identity of user who is exposed } \\
\text { online }\end{array}$ & Privacy of data; analysis of user's demographic data \\
\hline $\begin{array}{l}\text { Conversa- } \\
\text { tions }\end{array}$ & $\begin{array}{l}\text { To what degree users communi- } \\
\text { cate with each other }\end{array}$ & $\begin{array}{l}\text { Following an enormous number of different forms and protocols of com- } \\
\text { munication; analysis of consumers' satisfaction my means of comments }\end{array}$ \\
\hline Sharing & $\begin{array}{l}\text { Exchange, distribution and accept- } \\
\text { ing of content among users }\end{array}$ & $\begin{array}{l}\text { Analysis of mutual goals of users and identification of new services that } \\
\text { could be interesting to users }\end{array}$ \\
\hline Presence & Availability of users & Identifying user's location, tracking their movement online or in real life \\
\hline Relationships & $\begin{array}{l}\text { To what degree are users intercon- } \\
\text { nected }\end{array}$ & $\begin{array}{l}\text { Tracking of connections with the aim of building and maintaining rela- } \\
\text { tions with users }\end{array}$ \\
\hline Reputation & $\begin{array}{l}\text { The trust which users identify with } \\
\text { the others, and with themselves }\end{array}$ & $\begin{array}{l}\text { Special metrics are used for measuring users' reputation, whether via } \\
\text { ranking systems or via number of views, likes, fans, etc. }\end{array}$ \\
\hline Groups & $\begin{array}{l}\text { To what degree can users form } \\
\text { communities }\end{array}$ & $\begin{array}{l}\text { It does not only include the tracking of one group's user list, but also dif- } \\
\text { ferent privilegies they have }\end{array}$ \\
\hline
\end{tabular}

Table 3. Functional framework of social networks with problem description.

Source: Kietzmann et al. (2011) 
The issue that emerges here relates to the choice of measures and metrics. Analytical framework makes reaching these answers easier. There are two approaches to the use of web analytics:

- Top-down analytics (analytics from the top to bottom) first defines the goals and then identifies metrics

- Bottom-up analytics starts without clearly defined goals. It includes tracking the content via gathering knowledge and defining goals afterwards.

In order to define specific metrics, it is necessary to define key performance indicators, and in order to establish those, it is necessary to be familiar with the business plans of a company. In order for such business aims to be realised, it is necessary to take into account targets and segments. Bearing this in mind, Kaushik (2014) suggests web analytics framework which is an indicator of quantitative content analysis (Table 5):

1. Defining business goals: In order to successfully define business goals, it is necessary to answer several questions, such as: What is the purpose of a website? Some examples of business goals are: to increase the awareness of brand existence; to improve communication and feedback systems; to improve efficiency of marketing and public relations; to improve customer services and operational efficiency.

2. Defining content goals: After understanding business goals, it is necessary to define specific goals of website content, i.e. which actions users can perform on this website. The examples of content goals are: to read an article, to leave a comment, to subscribe, to fill in a form, to download brochures, to follow someone on social networks etc.
3. Defining key performance indicators (Key Performance Indicators, KPI): The following question is answered within this part: Which relevant web metrics can be used to measure the content goals? The examples of KPI indicators and goals are shown in the following table:

\begin{tabular}{ll}
\hline \multicolumn{1}{c}{ Content goals } & Key performance indicators \\
\hline To read an article & $\begin{array}{l}\text { Average time spent on social } \\
\text { network }\end{array}$ \\
\hline To leave a comment & Conversion rate \\
\hline To subscribe & Number of subscriptions \\
\hline $\begin{array}{l}\text { To download } \\
\text { brochures }\end{array}$ & $\begin{array}{l}\text { Number of downloaded } \\
\text { brochures }\end{array}$ \\
\hline $\begin{array}{l}\text { To follow someone on } \\
\text { social networks }\end{array}$ & Percentage of fans (followers) \\
\hline $\begin{array}{l}\text { * Conversion rate represents a process of turning the visitors of a web- } \\
\text { site into real buyers. For instance, when a visitor wants to leave the } \\
\text { website, the company markets a special offer. }\end{array}$
\end{tabular}

Table 4. Comparing goals and KPI indicators.

4. Defining targets: Aside from establishing goals and identifying metrics, it is necessary to understand what their values mean. For example, if the metrics shows that there are 2000 views of a page, the question that imposes is whether these figures are good or bad. If the last year's number of views was 3000, a drop could undoubtedly be observed.

5. Segmentation: One of the most powerful functions of web analytics is the possibility of data segmentation. Here, it is considered how to segment the data according to visitor attributes. For instance, if a company has profiles on most of the social networks, and not enough staff or time, it is necessary to decide on prioritising social channels in order to promote events and other services. By segmenting web

\begin{tabular}{cll}
$\begin{array}{c}\text { Web analytics } \\
\text { framework }\end{array}$ & \multicolumn{1}{c}{ Description } & Example \\
\hline Business goals & What is the purpose or use of a website? & To intensify online/offline marketing \\
\hline Website goals & Which activities are available on a website? & $\begin{array}{l}\text { Increasing the awareness of a brand } \\
\text { online }\end{array}$ \\
\hline $\begin{array}{c}\text { Key performance } \\
\text { indicators }\end{array}$ & $\begin{array}{l}\text { Which relevant web metrics can be used to meas- } \\
\text { ure website goals during a period of time? }\end{array}$ & Traffic related to brand \\
\hline Targets & How to measure success? & 12,000 visitors per month \\
\hline Segments & $\begin{array}{l}\text { Which visitor attributes will provide relevant busi- } \\
\text { ness insight? }\end{array}$ & Sources of traffic; converted visits \\
\hline
\end{tabular}

Table 5. Web analytics framework with examples.

Source: Kaushik (2014) 
traffic according to social media sources and content type, it is possible to draw a conclusion on which social networks are the best to use for the specific type of content. For example, the response of users to some events may be higher if they are posted on Twitter, while the response to business offers would be better on LinkedIn network.

Numerous vendors offer different web analytic tools on the market (Milic, 2013). In this paper, the results of Facebook reporting tools will be analysed. According to various analyses, Facebook is still the leading social network, either by the number of user profiles or by active user participation (Stelzner, 2014; Global Web Index, 2014).

Some of the basic Facebook tools available are (Hines, 2014):

1. Simply Measured: it offers reports for analysing competition on Facebook. Free Facebook tool Competitive Analysis Report shows the last two weeks of a user's activity for the maximum of 10 web profiles of the competition. Report of Facebook Fan Page Report shows performance and activity of users on web pages. Facebook Insights Report shows detailed insight into posts and likes of users. Report of Facebook Content Analysis identifies the best types of posts regarding user activity.

2. Social Bakers: enables overseeing of the company's, or competition's Facebook, Twitter and YouTube profiles.

3. Sprout Social: a popular tool for managing social media. It observes movement and activities of website visitors.

4. Rival IQ: it enables comparing a Facebook page with the competition, showing basic metrics such as the number of likes, posts, engagement relations, etc.

\section{A CASE STUDY: COMPARATIVE ANALYSIS OF FACEBOOK FAN PAGES OF MOUNTAIN HOTELS IN ZLATIBOR, STARA PLANINA AND KOPAONIK}

Tourist centres in Serbian mountains have been rapidly developing over the last several years, by making their capacities and programmes available during the whole year. Those programmes mostly consist of a set of different holiday and recreational activities, depending on the season. Besides climate, these mountain destinations are attractive to tourists for various reasons including clear air, flora and fauna, natural beauties, local culture, history and heritage. Tourists can also take part in different sport activities - winter sports, hiking, cycling, walking tours, horse riding, etc. Since tourism operates in a highly competitive environment, with many distinguished as well as newly-established tourist destinations in region, it is clear that its development should be managed professionally (Horwath Consulting Zagreb \& Ekonomski fakultet Beograd, 2005).

Serbia has more than 20 skiing areas, with most popular skiing resorts located in Kopaonik, Zlatibor and Stara planina. All three destinations received certificates from the International Ski Federation (FIS), which confirms that ski resorts meet all the standards set for international competitions. Advanced skiing infrastructure enabled Serbia to achieve the level necessary for international ski destination (Vanat, 2014).

In recent years, online consumers have become increasingly more aware of how precious the Internet is for comparing prices, quality and tourist experience. Technology is becoming a crucial determinant for evaluating satisfaction of hotel guests, as well as differentiation of services and claiming competitiveness (Cobanoglu et al., 2011).

The following part of the paper shall elaborate on the position of hotels using Facebook social network. The data regarding 10 rival hotels belonging to similar categories and offering similar services are being compared (Table 6). The observed period ranges between January 7 and January 20, 2015.

\begin{tabular}{cl}
\hline Mountain & \multicolumn{1}{c}{ Name of the hotel } \\
\hline Stara Planina & Stara Planina Falkensteiner \\
\hline Kopaonik & $\begin{array}{l}\text { Junior, MK Mountain Resort, Putnik, } \\
\text { Mount }\end{array}$ \\
\hline Zlatibor & $\begin{array}{l}\text { Zlatibor Mona, Zlatiborska Noc, Palisad, } \\
\text { Olimp }\end{array}$ \\
\hline
\end{tabular}

Table 6. List of analysed hotels

\section{Data analysis}

The results of Simply Measured analytical tool show the percentage of fans per selected rival hotel (Figure 1). By analysing data, we can conclude that the total number of all hotel fans is 178,412 , where the biggest number of fans belongs to hotel Mona in Zlatibor, namely 125,951 of them, immediately followed by hotel MK Mountain Resort with 33,193 fans. Hotel Stara Planina - Falkensteiner is in the third place with 5,482 fans. 


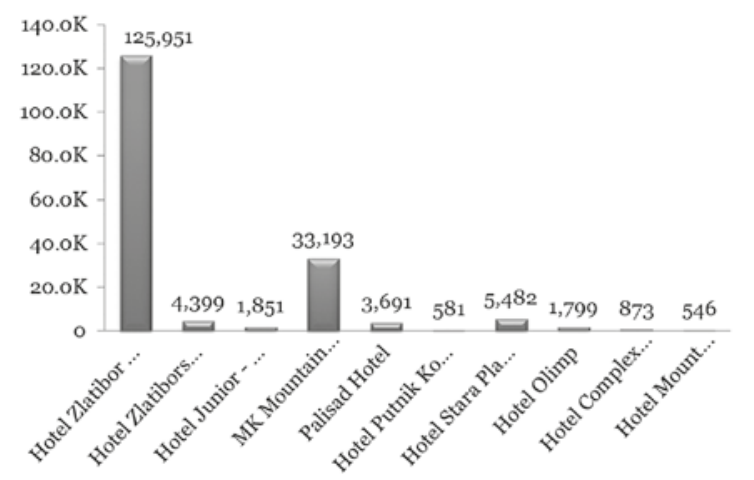

Figure 1. Comparing hotels by number of fans

PTAT parameter (People Talking About This) represents a unique story created by Facebook users about some brand, hotel or celebrity page. By definition, the larger the number of people talking about certain Facebook page, the more popular and widespread that page is. According to PTAT parameter, the hotel Mona Zlatibor assumes the leading position with 2,062 fans talking about this hotel, while the hotel Falkenstenier assumes the 8th place with 64 fans talking about it (Figure 2). The average PTAT for these hotels is 364 . The leading hotel Mona has the share of $26 \%$ PTAT.

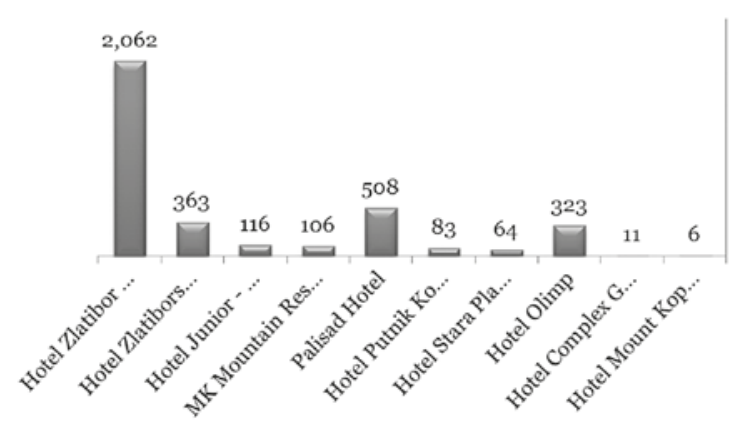

Figure 2. Hotel rankings according to PTAT parameter

User engagement is a parameter representing the sum of comments, likes, and shares to other users (so-called status or post sharing). Like represents liking of somebody's post, status, photo or video. The number of likes is an indicator of how much the users like somebody's activity on Facebook. Comments represent the reaction of a user to a status or post and reveal the opinion of other people on this status or post. Sharing of a status represents the number of people who share certain status with other users, and the number of shares shows how many times certain status has been multiplied on this social network and how often the useres have shared it with other users. According to the analysis, the highest number of active users has the hotel Mona in Zlatibor with 70\%, followed by the hotel Zlatiborska Noc with the share of $14 \%$, while hotel Falkenstenier participates with modest 2\% (Figure 3).

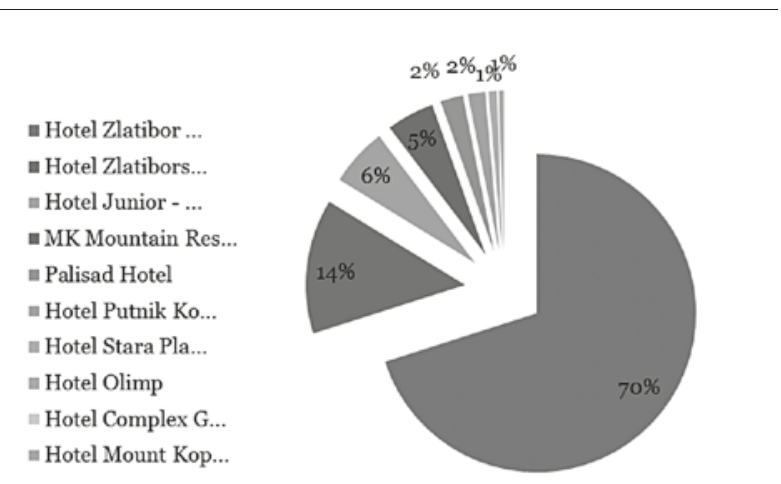

Figure 3. Relative share of user engagement

If the user engagement is analysed in relation to the number of fans a hotel page has, the biggest number of engaged users belongs to the hotel Junior with 376 users, i.e. $40.6 \%$ of engagement in relation to other hotels. The hotel Zlatiborska Noc assumes the $2^{\text {nd }}$ place with 886 active users, i.e. $39.4 \%$ share. Hotel Falkenstenier assumes the $7^{\text {th }}$ place with 54 active users, i.e. with $2 \%$ share (Figure 4 ).

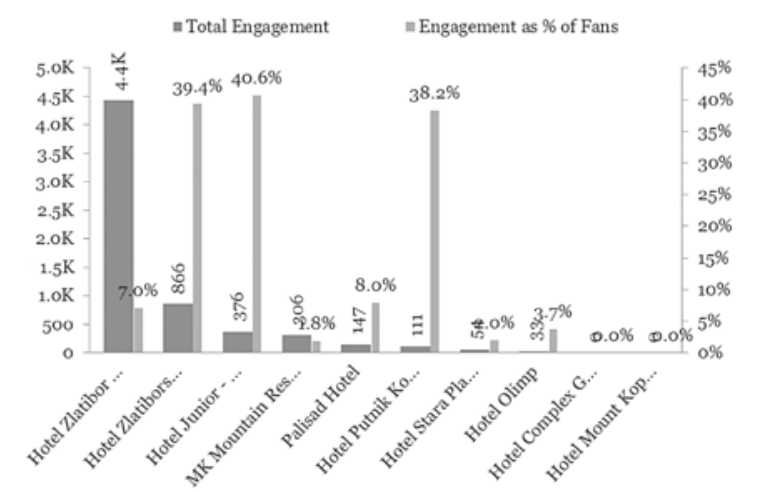

Figure 4. Total user engagement

When it comes to the number and frequency of status posting, it can be concluded that 10 hotels came up with 70 statuses altogether, which is approximately 7 statuses per hotel. The leading position in status posting has the hotel Putnik Kopaonik with 2.1 posts 
a day, while the hotel Mona assumes the $2^{\text {nd }}$ place with an average of 1.7 posts a day. Hotel Falkenstenier is in the $8^{\text {th }}$ place with the average number of posts of 0.1, while the hotels Complex Grand Kopaonik Spa and Mount Kopaonik do not have the daily activity of status posting (Figure 5).

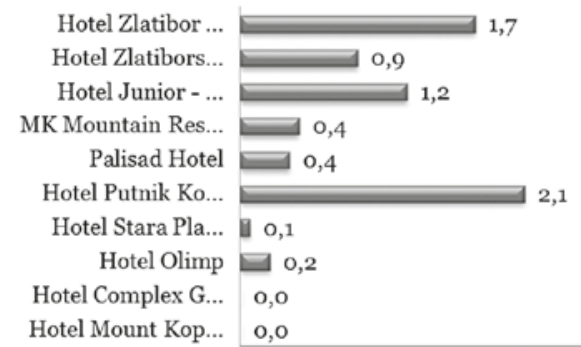

\section{Figure 5. Average number of hotel posts per day}

Out of the total number of posts, 86 are photos, i.e. $8.6 \%, 25$ are links (2.5\%), and 3 are videos, i.e. $0.3 \%$. Hotel Putnik combined all three types of content with 2 statuses, 1 link and 26 photographs, i.e. with the total of 29 posts. Hotel Zlatiborska Noc also combined all three types of content with 3 statuses, 2 links and 7 photographs, which comprises 12 posts altogether. Hotel Falkenstenier assumes the 7th place with the content of 3 photographs. Hotel Complex Grand Kopaonik Spa and Hotel Mount do not have daily posts (Figure 6).

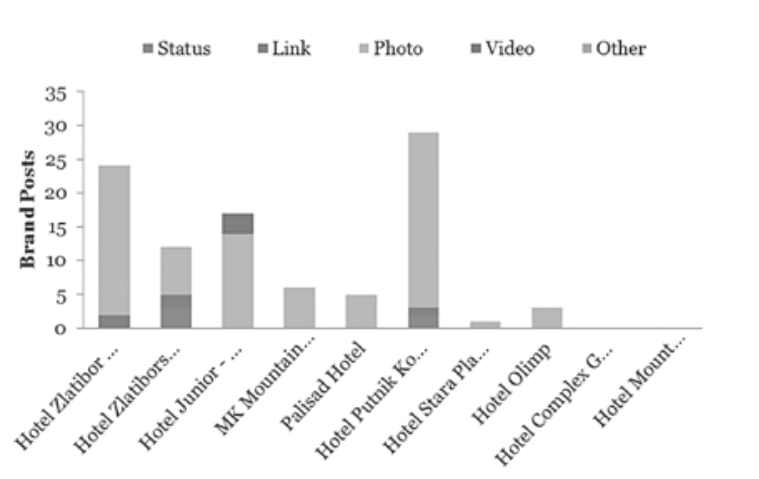

Figure 6. Number of hotel posts according to type

Observation and further analysis of the average rate of activity per post can lead to the conclusion that fans are more prone to like than to comment or share content. All 86 posts recorded 5,831 likes, which amounts to an average of 583 likes per hotel.
The number of comments triggered by posts is quite insignificant and amounts to 38 , which is approximately 4 per hotel, while the number of shares is 107 , averagely 10 per hotel (Figure 7).

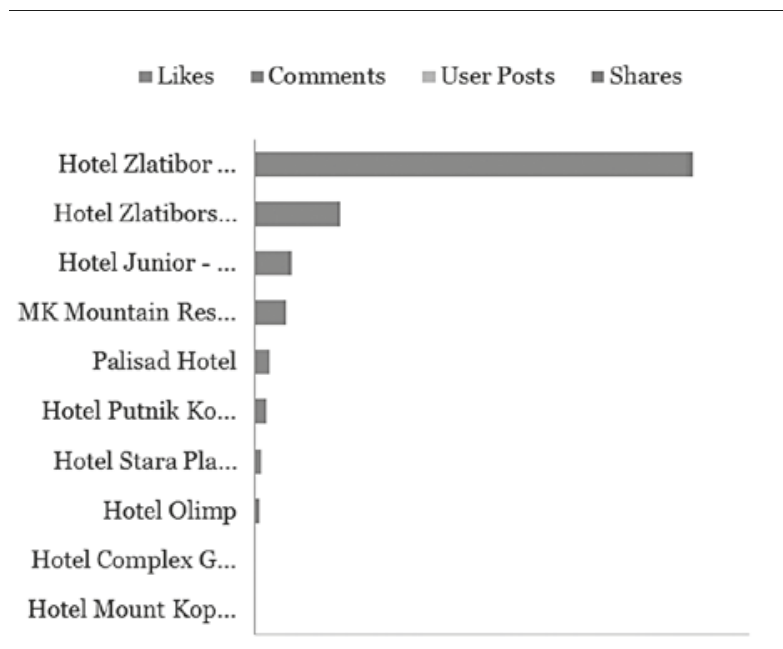

Figure 7. Comparative engagement of fans per hotel and type

By analysing the average activity of users preceding the hotel post, the data show that hotel Mona leads with 182 likes, 1 comment and 2 shares. It is followed by hotel Zlatiborska Noc with 70 likes, 1 comment and 2 shares. Hotel Falkenstenier Stara Planina assumes the third place with 53 likes, 0 comments and 1 share. MK Mountin Resort is in the $4^{\text {th }}$ place with 50 likes, 0 comments and 1 share. Hotel Palisad has 28 likes, 1 comment and no shares. Hotels with the worst engagement are hotel Putnik, hotel Olimp, hotel Complex Grand Kopaonik Spa and hotel Mount, which on average have 3 likes, 1 comment and no shares (Figure 8).

It can be concluded that the posts of hotels Mona, Zlatiborska Noc and Falkensteiner are considered most interesting by the users, and thus hold the leading positions. Four hotels with the least engagement hold such positions due to users' disinterest in their posts. The analysis cannot confirm the exact correlation between the frequency rate of posts and the interest users have in a certain hotel. As regards that, the hotel Falkenstenier assumes the $8^{\text {th }}$ place according to frequency of posting, and the $3^{\text {rd }}$ place according to users' interest in the hotels belonging to this group. It can be concluded that the hotel rarely posts content on Facebook, but that the users find these rare posts interesting and worthy of sharing and liking. 


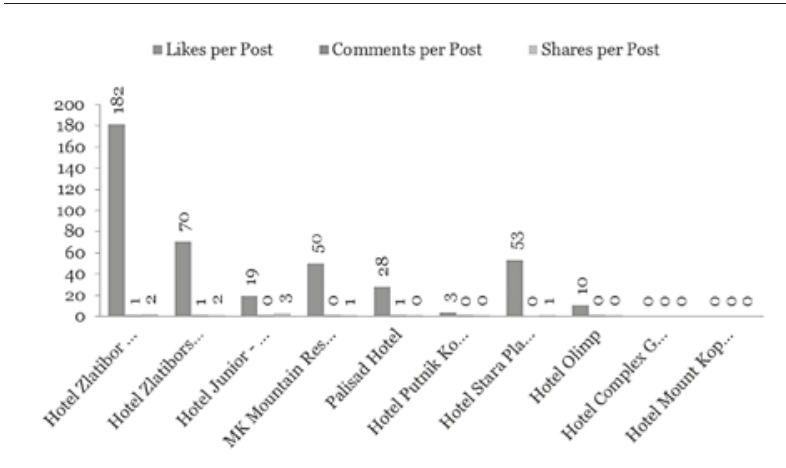

Figure 8. Average activity/engagement of users per hotel post

When it comes to comparing engagement/activity of fans, certain hotel posts, for the observed period, aroused engagement of over 100 users. The first post of the hotel Zlatiborska Noc was posted on January 7, 2015 with 675 likes, 5 comments and 17 shares. The second one is the post of hotel Mona, posted on January 11, 2015 with 599 likes, 12 comments and 3 shares. This hotel's posts assume the $3^{\text {rd }}, 4^{\text {th }}$ and $5^{\text {th }}$ place according to the number of likes (from 579 to 284), comments and shares. Hotel MK Mountin resort records 219 likes for the post from January 7, 2015 with 219 likes, 0 comments and 1 share. It can be concluded that these post have been most interesting to users for the given time frame and have left the most lasting impression (Table 7).

The post of Zlatiborska Noc hotel generated most likes with the text "Find your own heaven, package tour for two persons from February 13-16, 2015 for $€ 169$ ". The second post which aroused most attention of fans is the post by hotel Mona which has 599 likes and the text "Pieces of art on our smorgasbord. Do you like this piece?" with the posted photo of food on smorgasbord. We can conclude that 4 of 6 most popular posts belong to this very hotel, which is in correlation with the number of engaged users when it comes to this hotel. The posts of Falkenstenier hotel are not among the first 15 most popular posts according to the user engagement analysis.

Analytics used (Simply Measured, 2015) also gives an insight into the posts not created by the surveyed hotels, but which mention these hotels or are addressed to them on their profiles (walls). During the observed period, there were 7 of these posts, 3 of which were addressed to MK Mountain Resort, 2 to hotel Mona, 1 to hotel Junior and 1 to hotel Falkenstenier. These posts are mostly left by the guests who resided in a hotel, of which two are related to promotion of events held in a hotel and one is a link to a hotel photo taken during the New Year's holidays.

\section{SUMMARY}

Marketing is in charge of creating and delivering value for money to the consumers, and as a business function, it can be effective and efficient only if it cooperates with other business functions in the company on creating and delivering superior value to the consumers. It is wrong to think that attracting and keeping consumers is exclusively the task of those working in the area of marketing. The best marketing sector in the world cannot sell the products that are badly made or do not satisfy customers' needs. Satisfaction is an important element in the process of consumer decision-making, especially in repeated purchasing of products or services. It occurs during the evaluation phase, after purchasing, i.e. using the product or service. Satisfaction (pleasure) of guests is the key for keeping the old and attracting the new ones. As a rule, the high quality of products creates and maintains high level of consumer satisfaction. The research conducted in hotels at the most popular mountain destinations in Serbia shows that social networks can be successfully used by providers to improve and understand the needs of their guests, gain their loyalty, improve business outcomes and increase revenue.

\begin{tabular}{ccccccc}
\hline Hotel names & $\begin{array}{c}\text { Date of } \\
\text { posting }\end{array}$ & $\begin{array}{c}\text { Type of } \\
\text { post }\end{array}$ & $\begin{array}{c}\text { Number of } \\
\text { likes }\end{array}$ & $\begin{array}{c}\text { Number of } \\
\text { comments }\end{array}$ & $\begin{array}{c}\text { Number } \\
\text { of content } \\
\text { shares }\end{array}$ & $\begin{array}{c}\text { Total } \\
\text { engagement }\end{array}$ \\
\hline Hotel Zlatiborska Noc & 07.01 .2015 & photo & 675 & 5 & 17 & 697 \\
\hline Hotel Mona & 11.01 .2015 & photo & 599 & 12 & 3 & 614 \\
\hline Hotel Mona & 14.01 .2015 & photo & 579 & 1 & 1 & 582 \\
\hline Hotel Mona & 17.01 .2015 & photo & 296 & 12 & 309 \\
\hline Hotel Mona & 16.01 .2015 & photo & 284 & 0 & 0 & 284 \\
\hline Hotel Mk Mountin Resort & 07.01 .2015 & photo & 219 & 0 & 1 & 219 \\
\hline
\end{tabular}

Table 7. The most popular hotel posts

Source: www.simplymeasured.com 


\section{REFERENCES}

Clifton, B. (2014). Advanced Web Metrics with Google Analytics. New Jersey: John Wiley \& Sons.

Cobanoglu, C., Berezina, K., Kasavana, L.M., \& Erdem, M. (2011). The Impact of Technology Amenities on Hotel Guest Overall Satisfaction. Journal of Quality Assurance in Hospitality \& Tourism. 12(4), 272-288. DOI: 10.1080/1528008X.2011.541842

Cohena. S., Prayagb, G., \& Moitalc, M. (2014) Consumer behaviour in tourism: Concepts, influences and opportunities. Current Issues in Tourism. 17(10), 872-909. DOI: 10.4236/me.2011.25096

Fjelstul, J. (2013). Exploring Pull Factor Influences at Campgrounds by RV Association Members. Journal of Tourism Insights. 4(1), Article 2. DOI: 10.9707/2328-0824.1035

Fratu, D. (2011). Factors of Influence and Changes In The Tourism Consumer Behaviour. Bulletin of the Transilvania University of Braşov. 4(53), 119-126, Retrieved February 07, 2015, from http://webbut.unitbv.ro/bu2011/ Series\%20V/BULETIN\%20V\%20PDF/20\%20fratu $\% 20$ 1\%20BUT\%202011.pdf

GlobalWebIndex. (2014). GWO Social Q3 2014. GlobalWebIndex's quarterly report on the latest trends in social networking. Retrieved February 05, 2015, from http://www. scribd.com/doc/248201099/GWI-Social-Report-Q3-2014

Green, E.C., Lomano, V.M. (2012). Distribution Channel Analysis: a Guide for Hotels, HSMAI Foundation. Retrieved February 05, 2015, from http://www.owners.org/ Portals/1/Documents/NDP/DCA\%20Full_Part1.pdf

Gunelius, S. (2011). 30-Minute Social Media Marketing. Columbus: McGraw Hill.

Hines, K. (2014). 6 Facebook Reporting Tools for In-Depth Analysis of Fan Pages. Post Planner. Retrieved Feruary 05, 2015, from http://www.postplanner.com/6-facebookreporting-tools-in-depth-analysis-fan-pages/

Hoffman, D.L., \& Novak, T.P. (2009). Flow online: lessons learned and future prospects. Journal of Interactive Marketing. 23(1), 23-34. DOI: 10.1016/j.intmar.2008.10.003

Horwath Consulting Zagreb \& Ekonomski fakultet Beograd (2005). Strategija razvoja turizma Republike Srbije. Beograd: Ministarstvo trgovine, turizma i usluga. (In Serbian)

Jansen, B.J., \& Schuster, S. (2011). Bidding on the buying funnel for sponsored search and keyword advertising. Journal of Electronic Commerce Research. 12(1), 1-18. Retrieved February, 07, 2015, from http://web.csulb.edu/ journals/jecr/issues/20111/Paper1.pdf

Kanagaraj, C., \& Bindu, T. (2013). An Analysis of Push and Pull Travel Motivations of Domestic Tourists to Kerala. International Journal of Management \& Business Studies. 3(2), 112-118.
Kaushik, A. (2014). Web Analytics Fundamentals: Key Definitions and Framework. Market Motive. Retrieved February 06, 2015. from http://www.marketmotive.com/training/ flash/view_flv.php?cid=741\&resume=1\&mov=Web_Analytics_Fundamentals_Key_Definitions_And_Framework_Curriculum $\&$ dim $1=800 \& \operatorname{dim} 2=498 \& \mathrm{mmCatId}$ $=9 \&$ lang $=$ en $\&$ font $=$ Arial $\&$ csize $=18 \&$ ccolor $=$ EEEEEE $\&$ $\operatorname{dir}=/$ training/flash/\&backcolor $=888888 \&$ doc_id $=0$

Kietzmann, J.H., Hermkens, K., McCarthy, I.P. \& Silvestre, B. (2011) Social media? Get serious! Understanding the functional building blocks of social media. Business Horizons. 54, 241-251. DOI: 10.1016/j.bushor.2011.01.005

Kotler, P., Kartajaya, H. \& SetiaWan, I. (2010). Marketing 3.0: From Products to Customers to the Human Spirit. New Jersey: John Wiley \& Sons.

Maričić, B. (2011). Ponašanje potrošača. Beograd: Ekonomski fakultet. (In Serbian)

Milic, L. (2013). Social Media Monitoring Tools and Services Report. Retrieved February, 05, 2015, from http://ideya. eu.com/images/SMMTools Excerpt FINAL 13082013. pdf

Minazzi, R. (2015). Social Media Marketing in Tourism and Hospitality. London: Springer.

Safko, L. (2010). The Social Media Bible: Tactics, Tools and Strategies for Business Success. New Jersey: John Wiley $\&$ Sons.

Servon, L.J. (2002). Bridging the Digital Divide: Technology, Community, and Public Policy. Oxford: Blackwell Publishers.

Solomon, M.R. (2011). Consumer Behavior: Buying, Having, and Being. Boston: Pearson/Prentice Hall.

Stelzner, M.A. (2014) 2014 Social Media Marketing Industry Report: how Marketers are Using Social Media to Grow Their Business. Social Media Examiner. Retrieved February, 05, 2015, from http://www.socialmediaexaminer. com/SocialMediaMarketingIndustryReport2014.pdf

Vanat, L. (2014). International Report on Snow \& Mountain Tourism. Retrieved February, 05, 2015, from http://www. isiaski.org/download/20140517_ISIA_Vuokatti_1b_ presentation_vanat.pdf

Živković, R. (2013). Ponašanje i zaštita potrošača u turizmu. Beograd: Univerzitet Singidunum. (In Serbian)

Živković, R., Gajić, J., \& Brdar, I. (2012). Turisti kao pokretači inovacija u turizmu. U: Turistička privreda i povezane teme: tematski zbornik radova / Sedmi naučni skup sa međunarodnim učešćem Turizam: izazovi i mogućnosti, Trebinje, 20-22. septembar 2012. Beograd: Ekonomski institut. (In Serbian) 


\section{UPOREDNA ANALIZA FACEBOOK KOMUNIKACIONIH AKTIVNOSTI PLANINSKIH HOTELA NA STAROJ PLANINI, KOPAONIKU I ZLATIBORU}

\section{Rezime:}

Komunikacione strategije sa korisnicima turističkih proizvoda i usluga su se znatno promenile tokom poslednjih godina sa pojavom društvenih medija i onlajn informacija. Prema mišljenju brojnih autora, društveni mediji predstavljaju hibridnu formu tradicionalnih integrisanih marketinških komunikacija uz uvećan efekat WOM (word of mounth) komunikacija, koje omogućavaju razmenu informacija između korisnika/potrošača. Transparentnost društvenih medija pruža hotelijerima povratne informacije i otvara nove komunikacione kanale. Današnji potrošači poseduju veća znanja i imaju veća očekivanja nego ikada pre. Cilj rada je da ukaže na vrednost i značaj onlajn komunikacija u turizmu i hotelijerstvu, kako bi se razvile efikasnije marketing komunikacione strategije i aktivnosti. Zadatak istraživanja je da na primeru planinskih hotela u Srbiji ispitamo percepciju i zadovoljstvo gostiju u posmatranim hotelima korišćenjem web metrike. Nakon sprovedenog istraživanja u hotelima na najpopularnijim planinskim destinacijama u Srbiji, došli smo do saznanja da se društvene mreže mogu uspešno koristiti od strane pružaoca usluga sa namerom da se što bolje razumeju potrebe klijenata, a sa ciljem poboljšanja poslovnog uspeha i ukupnih prihoda. Kroz očuvanje dobrih odnosa sa gostima, hotelijeri mogu da izgrade čvršće i trajnije veze koje će rezultirati ponovnom posetom i efikasnijom usmenom propagandom.
Ključne reči:

marketinške komunikacije, planinski hoteli, društveni mediji, potrošači.

Received: March 10, 2015. Correction: March 22, 2015. Accepted: April 10, 2015. 